\title{
Učinkovitost liječenja bola terapijom udarnog vala u plantarnom fascitisu, kalcificirajućem tendinitisu ramena i lateralnom epikondilitisu lakta
}

\section{Efficacy of pain treatment with shock wave therapy in plantar fasciitis, calcific tendinitis of the shoulder and lateral epicondylitis of the elbow}

\author{
Tanja Grubić Kezele ${ }^{1 *}$, Jan Nemrava², Tamara Kauzlarić-Živković3 ${ }^{3}$ Luka Đudarić ${ }^{4}$, \\ Ariana Fužinac-Smojver ${ }^{5}$
}

\begin{abstract}
Sažetak. Uvod: Terapija udarnim valom (TUV) (od engl. shockwave therapy) je neinvazivna metoda temeljena na mehaničkim pulsovima koji se u obliku vala šire kroz ljudsko tijelo te izazivaju mikroskopske intersticijalne i ekstracelularne biološke učinke među kojima je i regeneracija tkiva. Cilj: Cilj ovog retrospektivnog istraživanja bio je ispitati učinkovitost i razlike u liječenju bola TUV-om u pacijenata s dijagnozama plantarni fascitis, kalcificirajući tendinitis ramena i lateralni epikondilitis lakta nakon upotrebe tri i pet uzastopnih tretmana. Ispitanici $i$ metode: $\mathrm{U}$ radu su korišteni podatci pacijenata iz baze podataka Zavoda za fizikalnu i rehabilitacijsku medicinu Kliničkog bolničkog centra u Rijeci, a pri tome su u skladu s Helsinškom deklaracijom ostali anonimni: dob, spol, mjerenja intenziteta bola dobivena uz pomoć vizualno analogne skale (od engl. Visual Analogue Scale, VAS). Ispitanici su podijeljeni u dvije grupe za svaku dijagnozu (TUV3 i TUV5). Ispitivanje je sadržavalo ukupno 148 pacijenata: plantarni fascitis $N=50$, kalcificirajući tendinitis ramena $N=50$ i lateralni epikondilitis lakta $N=48$. Rezultati: Primjena terapije udarnim valom kod pacijenata $s$ dijagnozama plantarni fascitis, kalcificirajući tendinitis ramena i lateralni epikondilits lakta, s ciljem smanjenja intenziteta bola, pokazala se uspješnom. Dobivenim rezultatima utvrđeno je da primjena pet TUV tretmana dovodi do boljih rezultata smanjenja bola u sve tri dijagnoze negoli samo tri primijenjena tretmana $(p<0,001 ; p<$ $0,001 ; p<0,001)$. Nadalje je utvrđeno da se nakon tri primijenjena tretmana postigao bolji učinak smanjenja bola kod plantarnog fascitisa negoli kod kalcificirajućeg tendinitisa ramena $i$ lateralnog epikondilitisa lakta, dok nakon pet primijenjena tretmana nije bilo razlike u smanjenju bola među dijagnozama. Zaključak: Ova studija preporučuje primjenu pet tretmana kod sve tri dijagnoze kako bi pacijenti imali bolji učinak smanjenja bola.
\end{abstract}

Ključne riječi: bol; epikondilitis; plantarni fasciitis; tendinitis; terapija udarnim valom

Abstract. Introduction: Shock wave therapy (SWT) is a non-invasive method based on mechanical pulses widening through the human body and causing microscopic interstitial and extracellular biological effects, including tissue regeneration. Aim: The aim of this retrospective study was to analyze efficacy and differences in pain treatment with SWT in patients with plantar fasciitis, calcific tendinitis of the shoulder and lateral epicondylitis of the elbow after three and five consecutive treatments. Participants and methods: The patients data were taken from the database at the Departmentof Physical and Rehabilitation Medicine of the Clinical Hospital Center in Rijeka and used only in purpose of this work, and according to the Helsinki Declaration, stayed anonymous: age, sex, pain intensity measurements obtained using the Visual Analogue Scale. The participants were devided into two groups (TUV3 and TUV5).

\begin{abstract}
${ }^{1}$ Zavod za fiziologiju i imunologiju, Medicinski fakultet Sveučilišta u Rijeci, Rijeka

${ }^{2}$ Zavod za fizikalnu i rehabilitacijsku medicinu - lokalitet Sušak, Klinički bolnički centar Rijeka, Rijeka

${ }^{3}$ Odjel za fizikalnu medicinu i rehabilitaciju, Thalassotherapia Opatija, Opatija

${ }^{4}$ Odjel za radiologiju, Opća bolnica Pula, Pula

${ }^{5}$ Katedra za temeljne medicinske znanosti,
\end{abstract} Fakultet zdravstvenih studija Sveučilišta u Rijeci, Rijeka 
The data were taken from 148 patients: plantar fasciitis $\mathrm{N}=50$, calcific tendinitis of the shoulder $\mathrm{N}=50$ and lateral epicondylitis of the elbow $\mathrm{N}=48$. Results: The therapy with SWT proved to be successful in patients with diagnosis of plantar fasciitis, calcific tendinitis of the shoulder and lateral epicondylitis of the elbow. The analyzed results showed that three or five treatments both resulted in pain reduction in all three diagnosis, with five treatments being more efficient than just three applied treatments ( $p<0,001 ; p<0,001 ; p<0,001)$. It has also been established that after three applied treatments a better effect of pain reduction is achieved in plantar fascitis than in calcific tendinitis of the shoulder and lateral epicondylitis of the elbow, and after five applied treatments there was no difference in pain reduction between diagnoses. Conclusion: Therefore, this study recommends the application of five treatments in all three diagnoses in order for patients to have better pain relief.

Key words: plantar fasciitis; tendinitis; epicondylitis; pain; shockwave therapy

Terapija udarnim valom ima brojne prednosti nad kirurškom intervencijom u vidu nepostojanja poslijeoperacijskog bola, ranijeg oporavka funkcije, nepostojanja mogućnosti infekcija kirurških rana, bržeg vraćanja uobičajenim aktivnostima.

\section{UVOD}

Terapija udarnim valom počinje biti opcija u sve više polja medicine. Medicinska primjena udarnog vala poprilično je izmijenila liječenje mnogih bolesti u medicini ${ }^{1}$. Termin "terapija udarnim valom" (TUV) (od engl. shockwave therapy, SWT) odnosi se na mehaničke pulsove koji se u obliku vala šire kroz ljudsko tijelo, odnosno koji prenose veliku količinu energije na bolno mjesto. Izvantjelesna terapija udarnim valom izaziva mikroskopske intersticijalne i izvanstanične biološke učinke među kojima je i cijeljenje tkiva² (slika 1). Proces prirodnog cijeljenja koštanog, tetivnog i okolnog mekog tkiva koje potiče, upravo nedostaje u kroničnim bolnim stanjima ${ }^{2}$. To postiže smanjenjem razine upalnih čimbenika (međustanične metaloproteinaze i citokine) te poticanjem neovaskularizacije i diferencijacije mezenhimalnih matičnih stanica putem pojačane sinteze čimbenika rasta poput Insulin-like Growth Factor 1 (IGF-I), Platelet-Derived Growth Factor (PDGF), Vascular Endothelial Growth Factor (VEGF), basic Fibroblast Growth Factor (b-FGF) i Transforming Growth

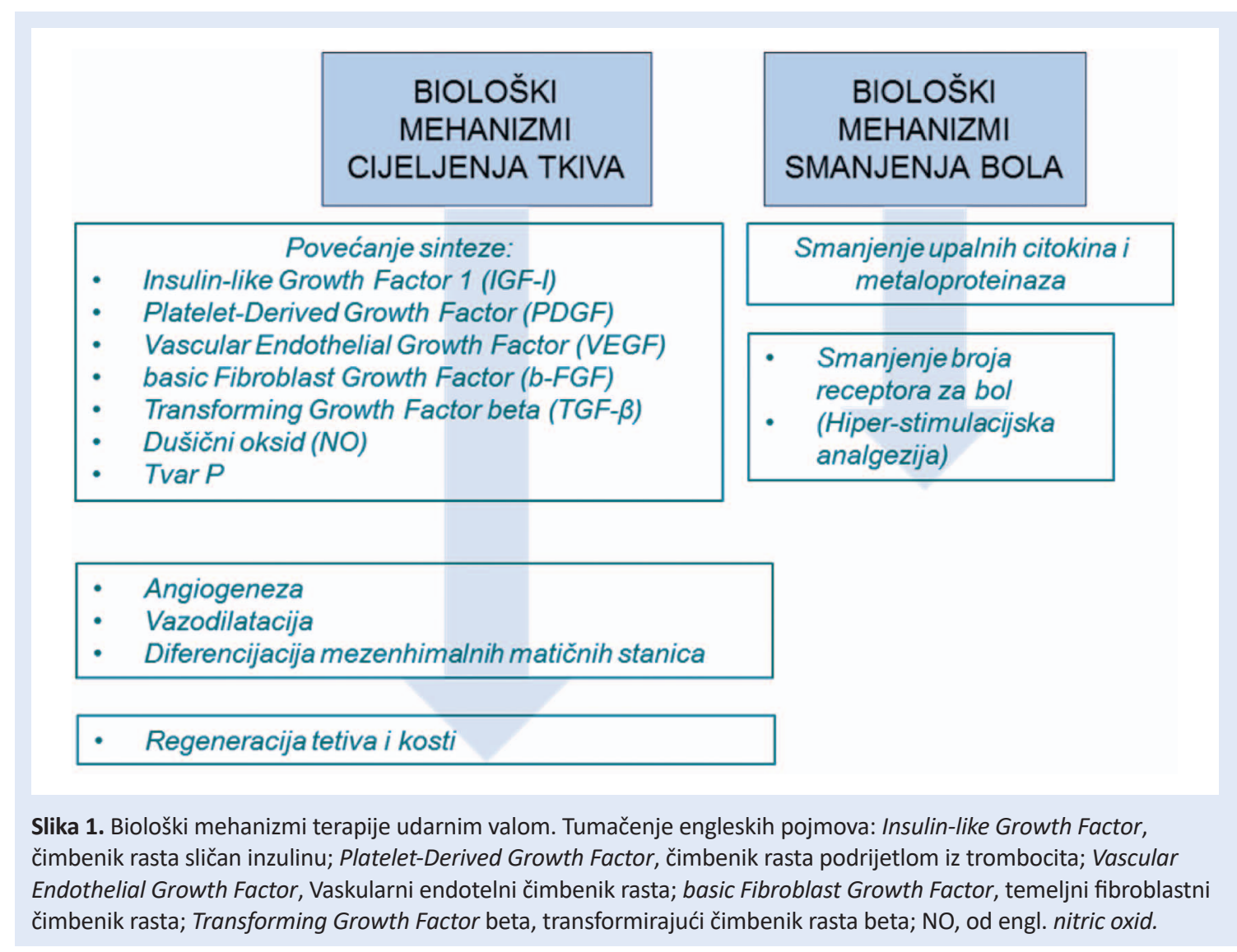


Tablica 1. Karakteristike ispitanika

\begin{tabular}{|l|c|c|c|}
\hline \multicolumn{1}{|c|}{ Karakteristike } & Plantarni fascitis & $\begin{array}{c}\text { Kalcificirajući tendinitis } \\
\text { ramena }\end{array}$ & $\begin{array}{c}\text { Lateralni epikondilitis } \\
\text { lakta }\end{array}$ \\
\hline N & 50 & 50 & 48 \\
\hline Dob $\left(g^{a}\right)$, SV $^{b} \pm$ SD $^{c}$ & $57,1 \pm 13,3$ & $56,5 \pm 11,5$ & $53,3 \pm 17,1$ \\
\hline Spol (N), Ž $/ M^{e}$ & $33 / 17$ & $25 / 25$ & $26 / 22$ \\
\hline VAS $^{f}$ prije tretmana, SV \pm SD & $7,3 \pm 1,7$ & $7,2 \pm 1,3$ & $6,6 \pm 1,5$ \\
\hline Grupa (N), TUV3 $/$ TUV5 $^{\text {h }}$ & $25 / 25$ & $21 / 29$ & $22 / 26$ \\
\hline
\end{tabular}

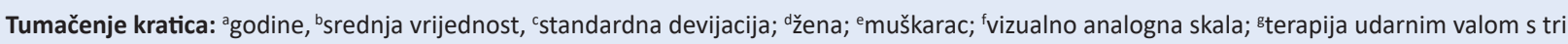

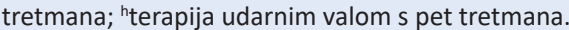

Factor beta (TGF- $\beta)^{2}$. Osim poticanja cijeljenja, smanjuje osjetljivost receptora za bol, a s tim i ukupnu bolnost (hiperstimulacijska analgezija) te razbija postojeće kalcifikate ${ }^{2}$. Udarni valovi pokazali su se kao učinkovita i neinvazivna metoda za liječenje lokaliziranih mišićno-koštanih patologija kao što su: epikondilitis lakta ${ }^{3}$, petni trn i plantarni fascitis ${ }^{4}$, poremećaj rotatorne manšete ${ }^{5}$, trigger točke ${ }^{6}$, niza kroničnih tendinopatija i mnogih drugih indikacija. Primjenjuje se u sportskoj medicini, ortopediji i fizioterapiji. Terapija udarnim valom zapravo je podražaj kojim se započinju procesi cijeljenja i nastavljaju se u tijelu i više tjedana nakon tretmana ${ }^{7,8}$. Prednosti udarnog vala su izbjegavanje operacije, sigurnost i efektivnost, a troškovi liječenja su vrlo razumni i prihvatljivi u usporedbi s operacijama. U provedenim studijama širom svijeta potvrđena je uspješnost terapije udarnim valom u 70 do $90 \%$ tretiranih pacijenata ${ }^{8}$. Prosječno je potrebno tri do pet, maksimalno do sedam tretmana u razmaku 7 do 10 dana između pojedinih tretmana ${ }^{9}$. Stručnjaci procjenjuju unaprijed broj tretmana na temelju težine kliničke slike. Ovdje se po prvi put uspoređuje uspješnost triju i pet tretmana u smanjenju bola u tri različite dijagnoze.

\section{CILJ ISTRAŽIVANJA}

Cilj je ispitati učinkovitost pet nad tri terapijska tretmana udarnim valom te ustanoviti postoji li razlika u krajnjem ishodu između pojedinih dijagnoza nakon tri i nakon pet terapijskih tretmana.

\section{ISPITANICI I METODE RADA}

\section{Ispitanici}

Podatci (mjerenja intenziteta bola, dob i spol) su uzeti iz baze podataka Zavoda za fizikalnu i reha- bilitacijsku medicinu u periodu od 2017. do 2018. godine, što je odobrilo Etičko povjerenstvo Kliničkog bolničkog centra u Rijeci. U svrhu istraživanja i izrade ovog rada podatci su ostali isključivo anonimni te se svakom pacijentu dodijelio broj umjesto osobnih podataka. Istraživanje je uključivalo ukupno 148 osoba, od kojih je 50 imalo dijagnozu plantarnog fascitisa, 50 kalcificirajući tendinitis ramena te 48 lateralni epikondilitis lakta (tablica 1). Podatci su sadržavali izmjereni intenzitet bola kod prvog dolaska pacijenta prije uvođenja tretmana te nakon svakog sljedećeg tretmana, u razmaku od 7 dana nakon tretmana. $U$ podgrupi pacijenata s plantarnim fascitisom bilo je 33 žena i 17 muškaraca u rasponu dobi od 25 do 79 godina te srednjom vrijednosti intenziteta bola mjerenom vizualno analognom skalom (engl. Visual Analogue Scale, VAS) ${ }^{10,11}$ 7,3. S kalcificirajućim tendinitisom ramena bilo je 25 žena i 25 muškaraca $u$ rasponu dobi od 27 do 76 sa srednjom vrijednosti intenziteta bola 7,2. $U$ podgrupi pacijenata $s$ lateralnim epikondilitisom lakta bilo je 26 žena i 22 muškaraca u rasponu dobi od 26 do 73 godine sa srednjom vrijednosti intenziteta bola 6,6.

Grupa s dijagnozom plantarnog fascitisa sadržavala je ukupno 50 pacijenata, od kojih je njih 25 primilo 3 uzastopna tretmana, a 25 je primilo 5 uzastopnih tretmana. U obje grupe je bilo više žena. U grupi TUV3 bilo je 8 muškaraca i 16 žena, dok je u grupi TUV5 bilo 9 muškaraca i 17 žena. Grupa s dijagnozom kalcificirajućeg tendinitisa ramena sadržavala je 50 pacijenata, od kojih je 21 primio 3 uzastopna tretmana, a 29 je primilo 5 uzastopnih tretmana. U obje grupe bilo je podjednako muškaraca i žena. U grupi TUV3 bilo je 11 muškaraca i 10 žena, dok je u grupi TUV5 bilo 
14 muškaraca i 15 žena. Grupa s dijagnozom lateralnog epikondilitisa lakta imala je 48 pacijenata, od kojih je njih 22 primilo 3 uzastopna tretmana, a njih 26 primilo je 5 uzastopnih tretmana. $U$ obje grupe bilo je podjednako muškaraca i žena. U grupi TUV3 bilo je 10 muškaraca i 12 žena, dok je u grupi TUV5 bilo 12 muškaraca i 14 žena.

Mehanizam djelovanja terapije udarnim valom je smanjenje osjetljivosti receptora za bol, a time i ukupne bolnosti te poticanje prirodnog procesa cijeljenja u tijelu, koji upravo nedostaje u kroničnim bolnim stanjima.

\section{Metode}

U terapiji je korišten Duolith sd1 tower uređaj (Storz Medical, Švicarska). Protokol liječenja udarnim valom uzet je iz priručnika za korištenje dobivenog s aparatom. Specifikacije za liječenje plantarnog fascitisa, lateralnog epikondilitisa lakta i kalcificirajućeg tendinitisa ramena utemeljene su na rezultatima završene kliničke studije provedene pod vodstvom Sveučilišta u Kölnu u Ruhu i Lausanne Ortopedskoj bolnici. Kod plantarnog fascitisa tretman je uključivao primjenu 3000 udarnih valova pod tlakom od 1,8 bara i frekvencije od $15 \mathrm{~Hz}$, dok se kod kalcificirajućeg tendinitisa ramena i lateralnog epikondilitisa lakta koristilo 2000 udarnih valova. Za procjenu fizičkog bola korišten je VAS za bol. VAS za bol je valjan i pouzdan standardizirani instrument za samoprocjenu intenziteta bola10,11. Njime su pacijenti naznačili svoj stupanj bola odabirom odgovarajućeg broja ispod slike izraza lica i pridruženih opisa, a sastojala se od 10 jedinica, tj. lica, gdje je 0 - bez bola i 10 - najteži mogući bol.

\section{Statistička obrada podataka}

Rezultati dobiveni istraživanjima statistički su obrađeni pomoću računalnog programa Statistica verzije 13 (Sigma Plot Scientific Graphing System, v13,0).

Prije testiranja značajnosti razlika u VAS vrijednostima koja su predmet ovog istraživanja izabran je

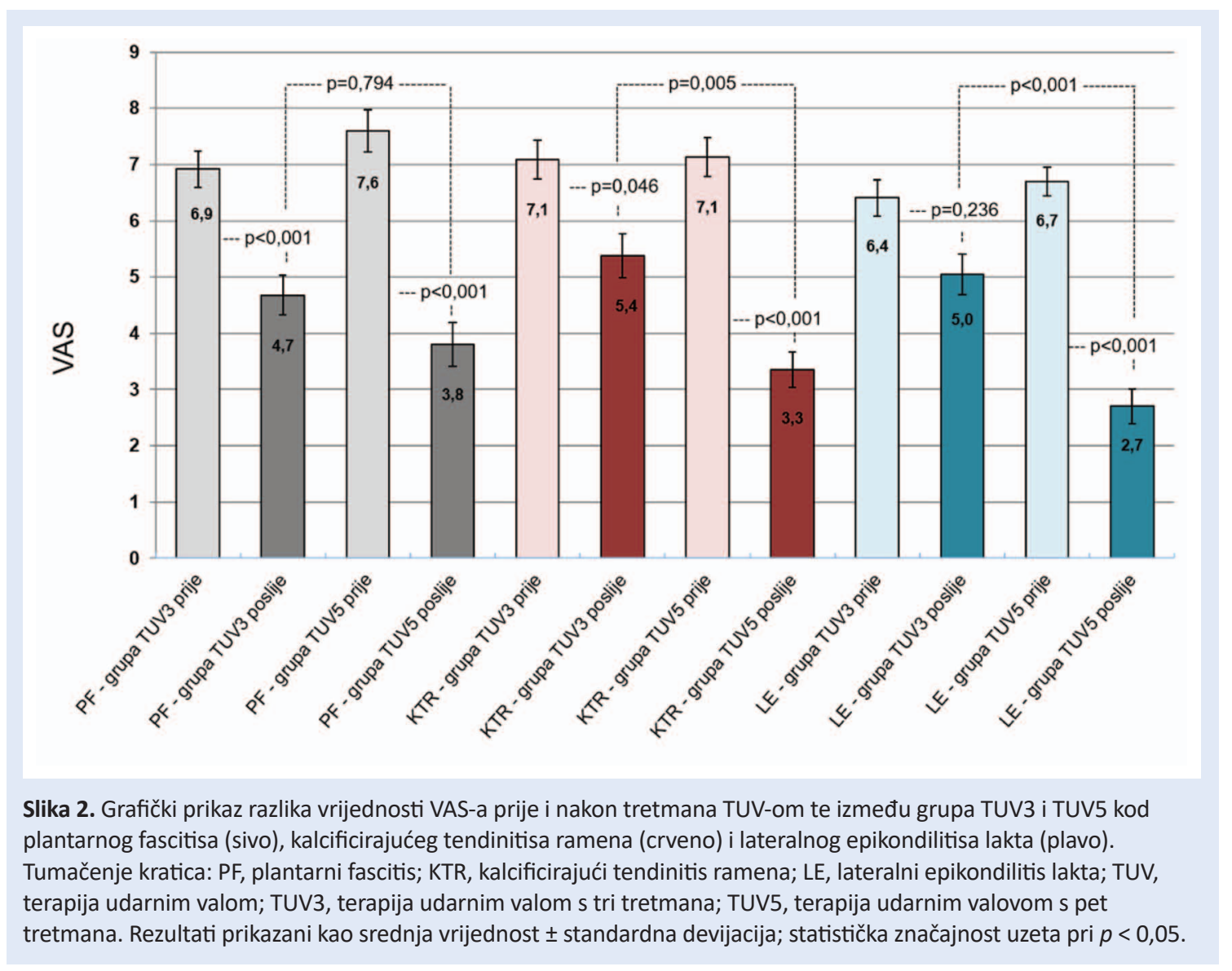


najprimjereniji statistički test s obzirom na normalnost raspodjele podataka. Normalna raspodjela podataka za VAS vrijednosti $(p>0,05)$ je potvrđena Kolmogorov-Smirnovljevim testom. Za ispitivanje razlika u učinku djelovanja terapije između pojedinih grupa (TUV3 i TUV5) korištena je analiza varijance za ponavljana mjerenja - miješani model (engl. 2-way mixed-model, repeatedmeasures analyses of variance - ANOVA), odnosno ANOVA s uključenim vremenom (prije i poslije) kao unutargrupnim čimbenikom te grupama (TUV3 i TUV5) kao međugrupnim čimbenikom $^{12-14}$. Za usporedbu podataka unutar i među grupama korišten je jednosmjerni ANOVA i post hoc Tukey-Kramerov test za nejednaki broj uzoraka.

Rezultati su izraženi kao srednja vrijednost (SV) sa standardnom pogreškom (SP) ili devijacijom (SD). Za korelaciju numeričkih podataka korišten je Pearsonov test. Statistički značajne promjene su smatrane uz $p<0,05$.

\section{REZULTATI}

\section{Usporedba VAS vrijednosti prije početka tretmana i nakon TUV tretmana kod plantarnog fascitisa, kalcificirajućeg tendinitisa ramena $\mathrm{i}$ lateralnog epikondilitisa lakta}

Utvrđena je statistički značajna razlika u prosječnim VAS vrijednostima prije i nakon tri tretmana (TUV3) kod pacijenata s plantarnim fascitisom ( $p$ $<0,001)$ slika 2 - sivo) i kalcificirajućim tendinitisom ramena ( $p=0,046)$ slika 2 - crveno), odnosno pacijenti $s$ plantarnim fascitisom i kalcificirajućim tendinitisom ramena su nakon primijenjena tri tretmana davali značajno niže procjene na VAS skali. Pacijenti s lateralnim epikondilitisom lakta koji su primili tri tretmana nisu pokazali statistički značajnu razliku u prosječnim VAS vrijednostima prije i nakon tretmana ( $p=$ 0,236) (slika 2 - plavo).

Utvrđena je statistički značajna razlika u prosječnim VAS vrijednostima prije i nakon pet tretmana (TUV5) kod pacijenata s plantarnim fascitisom ( $p$ $<0,001)$, kalcificirajućim tendinitisom ramena ( $p$ $<0,001$ ) i lateralnim epikondilitisom lakta ( $p<$ $0,001)$, odnosno, pacijenti koji su primili pet tretmana davali su značajno niže procjene na VAS skali kod svih triju dijagnoza (slika 2).
Razlike u učinku TUV tretmana na smanjenje bola nakon tri i pet tretmana kod plantarnog fascitisa, kalcificirajućeg tendinitisa ramena $i$ lateralnog epikondilitisa lakta

Usporedbom učinka terapije TUV nakon svih završenih tretmana između grupe $s$ tri dobivena tretmana i (TUV3) i grupe s pet dobivenih tretmana

A

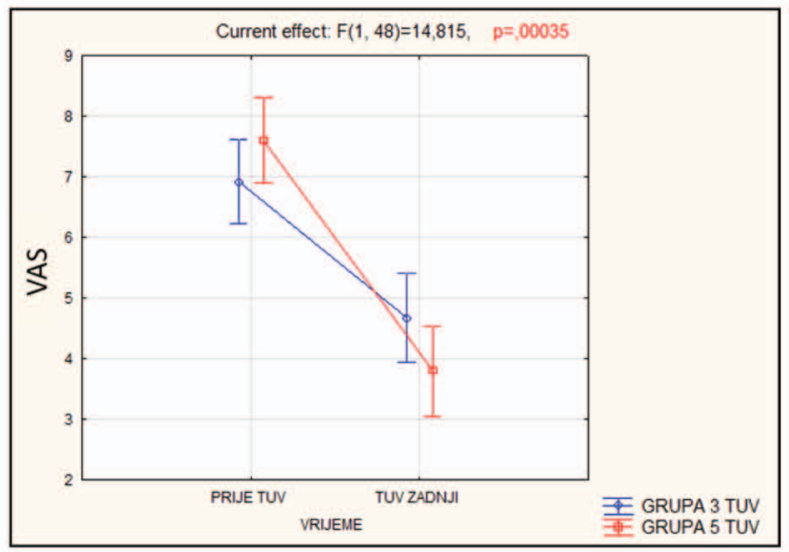

B

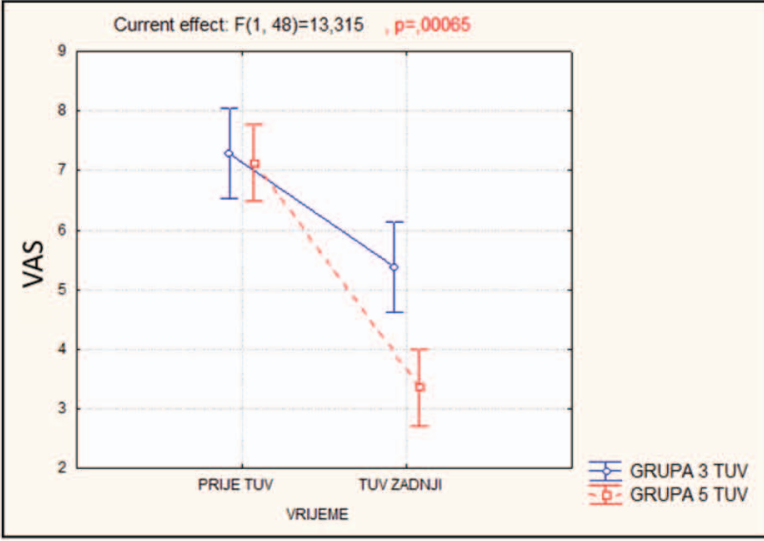

C

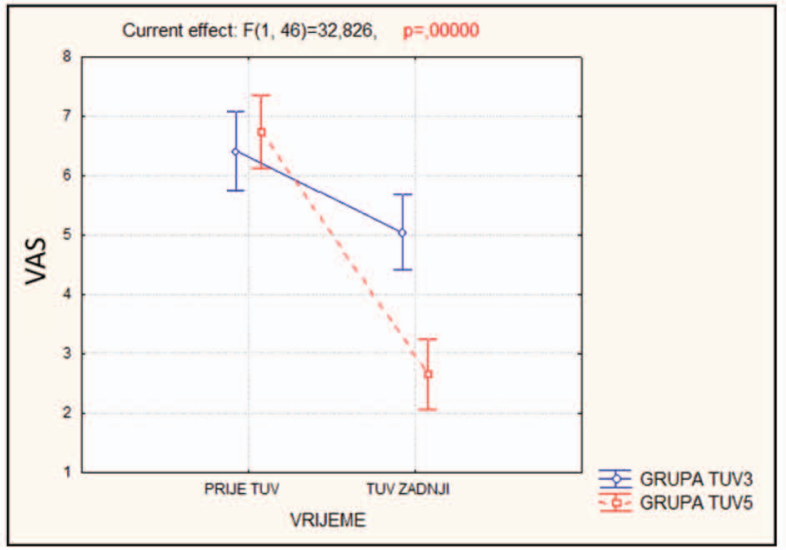

Slika 3. Prikaz razlika u učinku tretmana TUV-om između grupa TUV3 i TUV5 kod plantarnog fascitisa (A), kalcificirajućeg tendinitisa ramena (B) i lateralnog epikondilitisa lakta (C). Tumačenje kratica: TUV, terapija udarnim valom; 3 TUV, terapija udarnim valom s tri tretmana; 5 TUV, terapija udarnim valovom s pet tretmana. Rezultati prikazani kao srednja vrijednost \pm standardna devijacija; statistička značajnost uzeta pri $p<0,05$. 
(TUV5) dobivene su statistički značajne razlike $(p<0,001 ; p<0,001 ; p<0,001)$ kod plantarnog fascitisa (slika $3 \mathrm{~A}$ ), kalcificirajućeg tendinitisa ramena (slika 3B) i lateralnog epikondilitisa lakta (slika 3C), odnosno pacijenti koji su primili pet tretmana su davali značajno niže procjene na VAS skali u odnosu na one koji su primili samo tri tretmana kod svih triju dijagnoza.

\section{Razlike u učinku tretmana među dijagnozama}

\section{Učinci na bol nakon triju TUV tretmana}

Na slici 4A mogu se vidjeti usporedbe učinka terapije u grupi TUV3 između pojedinih dijagnoza zbirno, gdje se međusobno razlikuju konačni učinci

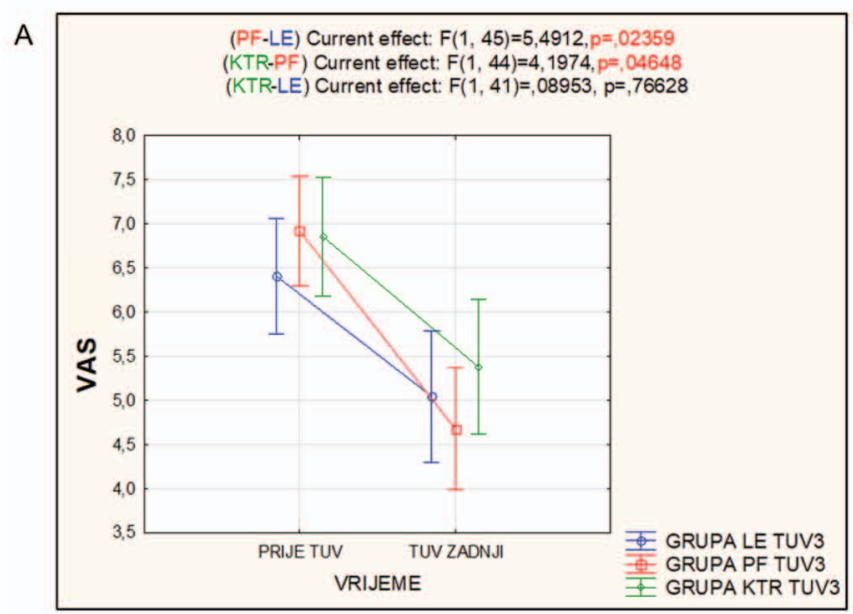

B

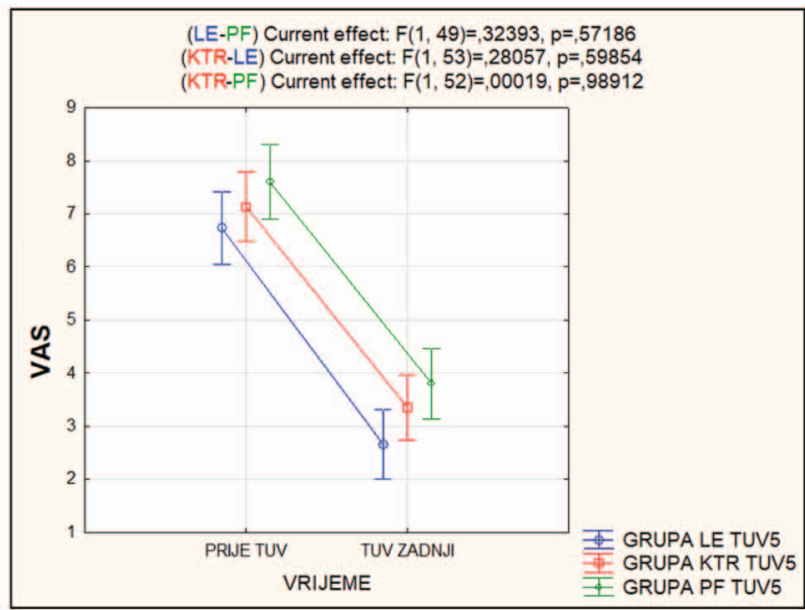

Slika 4. Prikaz razlika u učinku tretmana TUV-om unutar grupe TUV3 (A) i unutar grupe TUV5 (B) među svim trima dijagnozama. Tumačenje kratica i statističke obrade: TUV, terapija udarnim valom; PF, plantarni fascitis; KTR, kalcificirajući tendinitis ramena; LE, lateralni epikondilitis lakta; TUV3, terapija udarnim valom s tri tretmana; TUV5, terapija udarnim valovom $\mathrm{s}$ pet tretmana. Rezultati prikazani kao srednja vrijednost \pm standardna devijacija; statistička značajnost uzeta pri $p<0,05$. kod pacijenata s dijagnozom plantarnog fascitisa i lateralnog epikondilitisa lakta $(p=0,023)$, te plantarnog fascitisa $i$ kalcificirajućeg tendinitisa ramena $(p=0,046)$, dok se konačni učinci između pacijenata s lateralnim epikondilitisom lakta i kalcificirajućim tendinitisom ramena ne razlikuju ( $p$ $=0,766$ ). Time je utvrđeno da su pacijenti s dijagnozom plantarnog fascitisa davali značajno niže procjene na VAS skali nakon primljena triju tretmana TUV-om negoli pacijenti s dijagnozom kalcificirajućeg tendinitisa ramena i lateralnog epikondilitisa lakta.

\section{Učinak na bol nakon pet tretmana TUV-om}

Na slici 4B mogu se vidjeti usporedbe učinka terapije u grupi TUV5 između pojedinih dijagnoza zbirno, gdje se međusobno ne razlikuju konačni učinci u smanjenu bola između pacijenata s dijagnozom plantarnog fascitisa i lateralnog epikondilitisa lakta $(p=0,571)$, plantarnog fascitisa $\mathrm{i}$ kalcificirajućeg tendinitisa ramena $(p=0,989)$ te lateralnog epikondilitisa lakta i kalcificirajućeg tendinitisa $(p=0,598)$. Time je utvrđeno da su pacijenti s primljenih pet tretmana TUV-om davali značajno niže procjene na VAS skali u sve tri dijagnoze $u$ odnosu na one koji su primili samo tri tretmana (slika 4A).

\section{RASPRAVA}

Terapija udarnim valom je sve češće primjenjivana metoda liječenja pacijenata $s$ dijagnozom plantarnog fascitisa, kalcificirajućeg tendinitisa ramena i lateralnog epikodilitisa, posebice kada standardna fizikalna terapija ne daje zadovoljavajuće rezultate ${ }^{3-6}$. Mehanizam djelovanja ove metode ima dvije svoje sastavnice. Prva je smanjenje osjetljivosti receptora za bol, a s njom i smanjenje ukupne bolnosti. Druga i važnija je poticanje prirodnog procesa cijeljenja u tijelu, koji nedostaje upravo u kroničnim bolnim stanjima².

Primjenjuje se kod kroničnih entezopatija i tendinopatija (upala tetiva i njihovih hvatišta), s ili bez kalcifikata. Ona se koristi kao alternativa operativnom zahvatu, ali i poslije neuspjelih ostalih uobičajenih konzervativnih terapijskih metoda ${ }^{15}$. Dosadašnja iskustva u liječenju bola kod gore opisanih dijagnoza preporučuju TUV od tri do pet tretmana uz primjenu niske valne energije, dok 
se sedam terapija koristi kod masivnijih i konzistentnijih kalcifikata9.

Studije s primjenom metode TUV-om pokazuju pojačanu neovaskularizaciju na granici tetiva-kost s ranim otpuštanjem angiogenetskih i drugih čimbenika koji vode poboljšanoj krvnoj opskrbi i obnovi tkiva, što je vrlo značajan fiziološki proces u liječenju bolnog stanja i upale ${ }^{16,17}$.

U današnje vrijeme udarni val sve je češća linija obrane pacijenata prije kirurškog zbrinjavanja, jer ima brojne prednosti nad kirurškom intervencijom u vidu nepostojanja poslijeoperacijskog bola, ranijeg oporavka funkcije, nepostojanja mogućnosti infekcija kirurških rana, bržeg vraćanja uobičajenim aktivnostima ${ }^{18}$.

Korištenje udarnog vala prije operacija nikada nije ugrozilo ili pogoršalo ishod operacije ${ }^{19}$. lako primjena udarnog vala predstavlja još uvijek relativno neistraženo područje s neprecizno objašnjenim mehanizmima djelovanja, pokazalo se kao vrlo učinkovito oružje u tretiranju raznih patoloških stanja, naročito u mišićno-koštanom sustavu, te je sve više zastupljeno u fizikalnoj medicini i ortopediji kao prvi izbor liječenja prije ili umjesto operativnog zahvata.

Rezultati do sada provedenih studija pokazali su zadovoljavajuće rezultate u rasponu od 70 - $90 \%$ tretiranih pacijenata, što je izniman rezultat, uzme li se u obzir da je riječ o kroničnim i teško lječivim stanjima, kojima je jedina alternativa operativni zahvat ${ }^{8,20-23}$. Slijedom tih rezultata, američki FDA (od engl. Food and Drug Administration) odobrio je terapiju udarnim valom u liječenju lateralnog epikondilitisa lakta i plantarnog fascitisa u SAD-u, dok je u Europi, Kanadi, Australiji i Južnoj Americi ona uobičajena u liječenju kroničnih stanja kod ovih opisanih dijagnoza.

Dobivenim rezultatima u radu možemo zaključiti da $s$ pet tretmana dobivamo bolje rezultate $u$ odnosu na samo tri korištena tretmana u sve tri dijagnoze (slika 3). Također se utvrdilo da postoji razlika u konačnom smanjenu bola između spomenutih dijagnoza nakon samo triju tretmana, odnosno možemo reći da je terapijom metodom TUV-om kod plantarnog fascitisa postignut nešto bolji rezultat nakon trećeg tretmana u odnosu na druge dvije dijagnoze. To može biti očekivano, s obzirom na različitu kliničku težinu samih dijagnoza, ali i na to da su tri tretmana nedovoljna za bolji ishod u smanjenju bola kod kalcificirajućeg tendinitisa ramena i lateralnog epikondilitisa lakta, što se može vidjeti i na grafičkom prikazu na slici 2 . S obzirom na to da pacijenti s dijagnozom kalcificirajućeg plantarnog fascitisa i lateralnog epikondlitisa dolaze na pregled kada je patološki proces već znatno uznapredovao, razumljivo je zašto je potrebno više vremena, tj. terapijskih tretmana za potpun oporavak ${ }^{23,24}$.

Terapija udarnim valom potiče neovaskularizaciju na granici tetiva - kost $s$ ranim otpuštanjem angiogenetskih i drugih čimbenika koji vode poboljšanoj krvnoj opskrbi i obnovi tkiva, što je vrlo značajan fiziološki proces u liječenju bolnog stanja i upale.

Dobivenim rezultatima utvrđeno je da ne postoji razlika u konačnom smanjenu bola između spomenutih dijagnoza nakon pet tretmana, odnosno da je terapija metodom TUV-a, koja uključuje pet tretmana, imala jednak ishod u smanjenu bola između pojedinih dijagnoza u odnosu na samo tri tretmana. To ukazuje na važnost većeg broja tretmana u smanjenju bola u ove tri dijagnoze.

Slični radovi pri formiranju ispitivanih skupina posebno prate dob svih uključenih pacijenata ${ }^{4}$. Na taj način isključuju moguće slabije djelovanje udarnog vala kod starijih osoba, kod kojih se zbog sporijih metaboličkih procesa očekuje i sporije smanjivanje upale i regeneracije tkiva uz smanjivanje bola ${ }^{4}$. Ovo istraživanje, u kojem su bile uključene osobe svih dobnih skupina, pokazalo je jednako djelovanje udarnog vala, bez obzira na dob pacijenata.

lako je teško izravno usporediti studije zbog različitih parametara koji se koriste u tretmanima (gustoća energije, frekvencija, broj ispostavljenih udarnih valova po tretmanu, vremenski razmak tretmana, tip generatora) rezultati ishoda liječenja bili su slični ovoj studiji ${ }^{4,25-27}$. Pacijenti su pokazali značajno poboljšane rezultate na vizualno analognoj ljestvici za bol.

Budući da su pacijenti u ovom istraživanju imali dobre rezultate u smanjenju bola kod sve tri dijagnoze, naročito nakon pet provedenih tretmana, 
možemo zaključiti da su korišteni protokoli zadovoljavajući i da dovode do željenih rezultata. Predlažemo da se u budućim studijama s većim brojem pacijenata koriste protokoli iz ove studije, kako bi se zabilježili dugoročni rezultati i prikupili podatci za toleranciju pacijenata i prihvaćanje liječenja.

Moguća slabost ove studije, gdje je udarni val korišten kao monoterapija, njezin je dizajn i subjektivnost dobivenih rezultata. Stoga ova studija ispitivanja liječenja udarnim valom nema čvrstih dokaza za bolju uspješnost u usporedbi s drugim tehnikama liječenja.

\section{ZAKLJUČAK}

Primjena radijalnog udarnog vala kod pacijenata s dijagnozom plantarni fascitis, kalcificirajući tendinitis ramena i lateralni epikondilits lakta u cilju smanjenja intenziteta bola pokazala se uspješna. Kod svih tretiranih pacijenata korišteni su parametri liječenja koje je odredio proizvođač (gustoća energije, frekvencija, broj ispostavljenih udarnih valova po tretmanu, vremenski razmak tretmana, tip generatora). Kod primjene triju i pet tretmana kod sve tri dijagnoze terapija radijalnim udarnim valom pokazala se učinkovitom u smanjenju bola. Kod usporedbe učinkovitosti u smanjenju bola bolje rezultate dao je veći broj tretmana. Stoga možemo zaključiti da primjena pet tretmana radijalnim udarnim valom kod dijagnoza plantarni fascitis, kalcificirajući tendinitis ramena, lateralni epikondilitis lakta dovodi do bolje uspješnosti u smanjenju bola. Preporuka ove studije je da se kod sve tri dijagnoze provodi terapija od pet tretmana radi boljeg analgetskog učinka terapije i, pretpostavlja se, većeg zadovoljstva pacijenta.

\section{Zahvala}

Rad je proveden uz pomoć djelomične potpore Sveučilišta u Rijeci (broj: UNIRI uniri-biomed-18-41).

Izjava o sukobu interesa: Autori izjavljuju kako ne postoji sukob interesa.

\section{LITERATURA}

1. Schmitz C, Császár NB, Milz S, Schieker M, Maffulli N, Rompe JD et al. Efficacy and safety of extracorporeal shock wave therapy for orthopedic conditions: a systematic review on studies listed in the PEDro database. $\mathrm{Br}$ Med Bull 2015;116:115-8.
2. Notarnicola A, Moretti B. The biological effects of extracorporeal shock wave therapy (eswt) on tendon tissue. Muscle, Ligaments Tendons J 2012;2:33-7.

3. Carulli $C$, Tonelli F, Innocenti M, Gambardella $B$, Muncibì $F$, Innocenti M. Effectiveness of extracorporeal shockwave therapy in three major tendon diseases. J Orthop Traumatol 2016;17:15-20.

4. Wang YC, Chen SJ, Huang PJ, Huang HT, Cheng YM, Shih CL. Efficacy of Different Energy Levels Used in Focused and Radial Extracorporeal Shockwave Therapy in the Treatment of Plantar Fasciitis: A Meta-Analysis of Randomized Placebo-Controlled Trials. J Clin Med 2019;8: 1497.

5. Duymaz T, Sindel D. Comparison of Radial Extracorporeal Shock Wave Therapy and Traditional Physiotherapy in Rotator Cuff Calcific Tendinitis Treatment. Arch Rheumatol 2019;34:281-7.

6. Király M, Bender T, Hodosi K. Comparative study of shockwave therapy and low-level laser therapy effects in patients with myofascial pain syndrome of the trapezius. Rheumatol Int 2018;38:2045-52.

7. Taheri P, Khosrawi S, Mazaheri M, Parsa MA, Mokhtarian A. Effect of extracorporeal shock wave therapy on improving burn scar in patients with burnt extremities in Isfahan, Iran. J Res Med Sci 2018;23:81.

8. Dedes V, Stergioulas A, Kipreos G, Dede AM, Mitseas A, Panoutsopoulos GI. Effectiveness and Safety of Shockwave Therapy in Tendinopathies. Mater Sociomed 2018;30:131-46.

9. icacommission.org [Internet]. Shock waves in medicine and lithotripsy. 17th ICA Proceedings, Rome 2001: Proceedings of the 17th International Congress on Acoustics; 2001 Sept 2-7; Rome, Italy. Volume IV, Biomedicine [cited 2018 Jul 9]. Available from: https://www.icacommission.org/Proceedings/ICA2001Rome/7_09.pdf.

10. Kersten P, White PJ, Tennant A. Is the pain visual analogue scale linear and responsive to change? An exploration using Rasch analysis. PLoS One 2014;9:e99485.

11. Kane RL, Bershadsky B, Rockwood T, Saleh K, Islam NC. Visual Analog Scale pain reporting was standardized. J Clin Epidemiol 2005;58:618-23.

12. Ray AD, Udhoji S, Mashtare TL, Fisher NM. A combined inspiratory and expiratory muscle training program improves respiratory muscle strength and fatigue in multiple sclerosis. Arch Phys Med Rehabil 2013;94:1964-70.

13. Grubić Kezele T, Babić M, Štimac D. Exploring the feasibility of a mild and short 4-week combined upper limb and breathing exercise program as a possible home base program to decrease fatigue and improve quality of life in ambulatory and non-ambulatory multiple sclerosis individuals. Neurol Sci 2019;40:733-43.

14. Grubić Kezele T, Matea Babić, Tamara Kauzlarić-Živković, Tamara Gulić. Combined upper limb and breathing exercise programme for pain management in ambulatory and non-ambulatory multiple sclerosis individuals: part II analyses from feasibility study. Neurol Sci 2020;41:6574.

15. Lo MY, Safran MR. Surgical treatment of lateral epicondylitis: a systematic review. Clinical orthopaedics and related research 2007;463:98-106.

16. electrotherapy.org [Internet]. University of Hertfordshire UK: Shock Wave Therapy [cited 2018 Jul 12]. Available from: http://www.electrotherapy.org/links. 
17. Wang $\mathrm{CJ}$, Huang $\mathrm{HY}$, Pai $\mathrm{CH}$. Shock wave-enhanced neovascularization at the tendon-bone junction: an experiment in dogs. J Foot Ankle Surg 2002;41:16-22.

18. Wang CJ. An overview of shock wave therapy in musculoskeletal disorders. Chang Gung Med J 2003;26:220-32.

19. Gerdesmeyer L, Wagenpfeil S, Haake M, Maier M, Loew $\mathrm{M}$, Wörtler $\mathrm{K}$ et al. Extracorporeal shock wave therapy for the treatment of chronic calcifying tendonitis of the rotator cuff: a randomized controlled trial. JAMA 2003;290:2573-80.

20. Wolgin M, Cook C, Graham C, Mauldin D. Conservative treatment of a plantar heel pain: long-term follow-up. Foot Ankle Int 1994;15:97-102.

21. Ogden JA. Extracorporeal shock wave therapy for plantar fasciitis: randomised controlled multicentre trial. BMJ 2003;327:75.

22. Buchbinder R, Ptasznik R, Gordon J, Buchanan J, Prabaharan $V$, Forbes A et al. Ultrasound-Guided Extracorporeal Shock Wave Therapy for Plantar Fasciitis: A Randomized Controlled Trial. JAMA 2002;288:1364-72.
23. De Carli A, Pulcinelli F, Delle Rose G, Pitino D, Ferretti A. Calcific tendinitis of the shoulder. Joints 2014;2:1306.

24. Vaquero-Picado A, Barco R, Antuña SA. Lateral epicondylitis of the elbow. EFORT Open Rev 2016;1:391-7.

25. Schmitz C, Császár NB, Milz S, Schieker M, Maffulli N, Rompe JD et al. Efficacy and safety of extracorporeal shock wave therapy for orthopedic conditions: a systematic review on studies listed in the PEDro database. $\mathrm{Br}$ Med Bull 2015;116:115-38.

26. Malliaropoulos $\mathrm{N}$, Thompson $\mathrm{D}$, Meke $\mathrm{M}$, Pyne $\mathrm{D}$, Alaseirlis $\mathrm{D}$, Atkinson $\mathrm{H}$ et al. Individualised radial extracorporeal shock wave therapy (rESWT) for symptomatic calcific shoulder tendinopathy: a retrospective clinical study. BMC Musculoskelet Disord 2017;6:513.

27. Spacca G, Necozione S, Cacchio A. Radial shock wave therapy for lateral epicondylitis: a prospective randomised controlled single-blind study. Eura Medicophys 2005;41:17-25. 